\title{
Studying the features of the implementation of underground coal gasification technology in terms of Lvivvuhillia SE
}

\author{
Pavlo Saik ${ }^{1}$, Roman Dychkovskyi ${ }^{1}$, Vasyl Lozynskyi ${ }^{1,}{ }^{*}$, Volodymyr Falshtynskyi ${ }^{1}$, Edgar \\ Cabana $^{2}$, and Leonid Hrytsenko ${ }^{1}$ \\ ${ }^{1}$ Dnipro University of Technology, 49006, Dnipro, Yavornytskoho Ave., 19, Ukraine \\ ${ }^{2}$ Universidad Nacional de San Agustin de Arequipa, 04000 Arequipa, San Agustin Str., 107, Peru
}

\begin{abstract}
Topical issues of the possibilities for changes in the coal extraction technology in terms of Stepova mine of Lvivvuhillia SE have been highlighted. Analysis of the current state of mining operations has been carried out. Design solutions as for introduction of the coal gasification technology in the life cycle of the mining enterprise has been proposed on the basis of the analytical, experimental, and industrial studies; the technology has been described. Percentage ratio of the output of combustion generator gases $\left(\mathrm{H}_{2}, \mathrm{CO}, \mathrm{CH}_{4}\right)$ has been identified; gas combustion value and efficiency of the process depending on certain changes in the blowing mixture composition supplied into the underground gas generator have been determined. Heat balance of the process of underground coal gasification has been studied making it possible to evaluate its energy balance. The algorithm to determine coal reserves in a mine pillar to be gasified has been proposed. Indices of the output of combustion generator gases from the gasification column have been defined. The relevant issues have been studied of ensuring the possibility of underground coal gasification technology when uncovering the mining extracted area for the underground gas generator operation.
\end{abstract}

\section{Introduction}

Development of the on-balance and off-balance reserves of the mines completing their life period or being closed down promotes the implementation of mobile, complex, and ecological technologies to mine those reserves [1-4]. Such technologies include underground coal gasification (UCG) In this context, the processes, based on the UCG technology, combine extraction of coal and its utilization for power and chemical production $[5,6]$. Ecological safety of the UCG process is stipulated by its controllability, hermetic state of the underground gas generator, and complex use of the cogeneration technologies within the closed cycle of purification and processing of the gasification products [7-9].

Development of the technological and technical as well as design solutions for the implementation of gasification technologies has made it possible to prolong considerably the

\footnotetext{
*Corresponding author: lvg.nmu@gmail.com
} 
operating period of a mining enterprise. That is possible owing to the cardinal reorientation of the coal-mining production processes. In terms of the traditional technology of coal extraction, stoping is the main component of a mining enterprise (mine); advance rate of the stoping is one of the determining factors effecting the coal output per certain period [10-12]. While implementing coal gasification technology, there appears such a component of a mining enterprise as a fire face which provides intense increment of the production, quality and diversity of the gasification products [1315]. There is a shift in the priority of a mining enterprise "coal extraction $\rightarrow$ coal gasification"; a process of diversification of the mine operation is launched by the implementation of certain business-projects of different economic industries of synchronous coal mining (Synchro-Mining Concept) in terms of the property portfolio of a mine [16-18]. At the same time, much attention is provided to development and improvement of imitating modelling [19, 20], mathematical modelling [21, 22] as well as software simulation implementation in mining [23, 24]. At the same time ecological and environmental impact must be also considered [25-27].

Thus, objective of the paper is to study efficiency of the implementation the coal gasification technologies in terms of Stepova mine of Lvivvuhillia SE.

\section{Methodology}

There is the following basis to substantiate parameters of the efficiency of coal gasification under the mine conditions and to adapt coal gasification depending on the technological parameters of the process of its conducting, mining and geological conditions, geomechanical and mining and engineering parameters: analysis of the practice of coal gasification stations [28-30], analytical studies [31-33], approbation and correction of the coal gasification parameters during the laboratory [34-37] and industrial experiments [3840]. At the same time geomechanical process of rock massif behavior during underground mining was also taken into account [41-43].

The efficiency of a gasification process was evaluated by studying material and heat indices of the process. To do that, the authors of the paper used the software product "MTB SPGU" which has been approbated industrially in terms of a gas generator (Barbara mine, Poland) [44, 45]. Initial data on the coal suitable for gasification (chemical and technical composition) and technological parameters of the conducting of the process (length of a fire face, thickness of a coal seam, type of a blowing mixture, water inflow) were introduced in the software calculation algorithm.

\section{Results and discussion}

Current state of mining operations at Stepova mine of Lvivvuhillia SE is represented on the extract from the plan of mine workings in terms of seam $n_{8}{ }^{\text {top }}$ of the level of 508 and $535 \mathrm{~m}$ (Fig. 1). The seam is dust- and gas-hazardous; it is not prone to rock bumps and coal and gas outbursts; and it is not also prone to spontaneous firing. Coal grade is $\mathrm{G}$ (gas coal); water inflow is $80.0 \mathrm{~m}^{3} /$ hour (a general-mine value); production capacity is 300 thous $\mathrm{t}$. As of 01.01.2019, on-balance reserves are 23.31 thous $t$, and commercial reserves are 15.09 thous $t$.

According to the analysis of the extract from the plan of mining operations for 2020 , stoping operations are planned in longwall No. 565. That longwall was put into operation in December 2019. It should be noted that belt entry 566 is not gobbed. It will be reused for the next longwall (No. 566). In terms of the position of a stoping of longwall No. 565 at the distance of $575 \mathrm{~m}$ from the main southern belt entry, $500 \mathrm{~m}$ of a ventilation drift have been already driven. Thus, when stoping operations in longwall 565 are over, the following extraction pillar, being 1025 long and $275 \mathrm{~m}$ wide, will be prepared timely. Thus the authors of the paper propose to select that site as the project area to implement the underground coal gasification technology. 
(a)

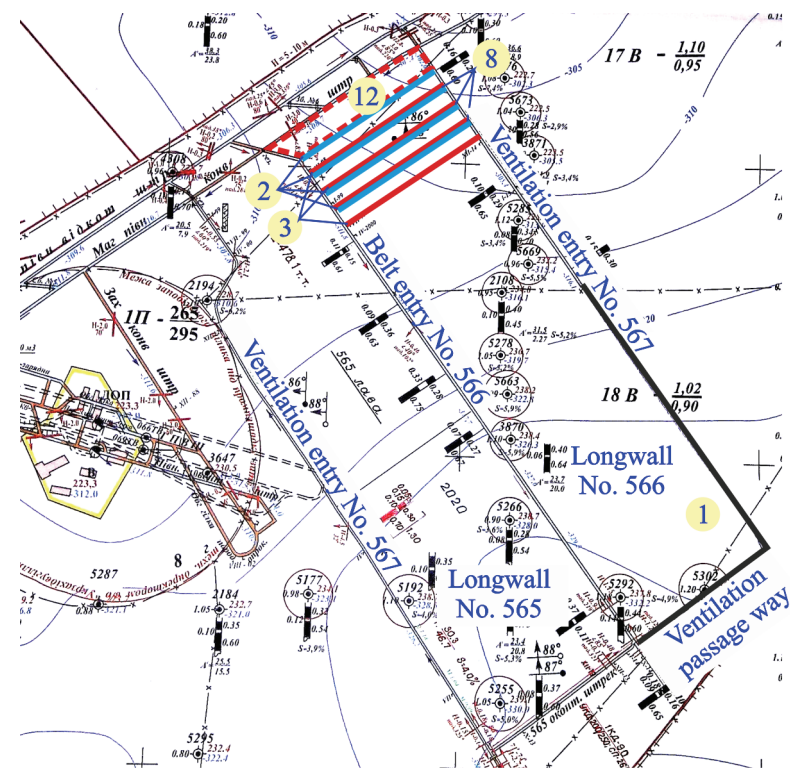

(b)

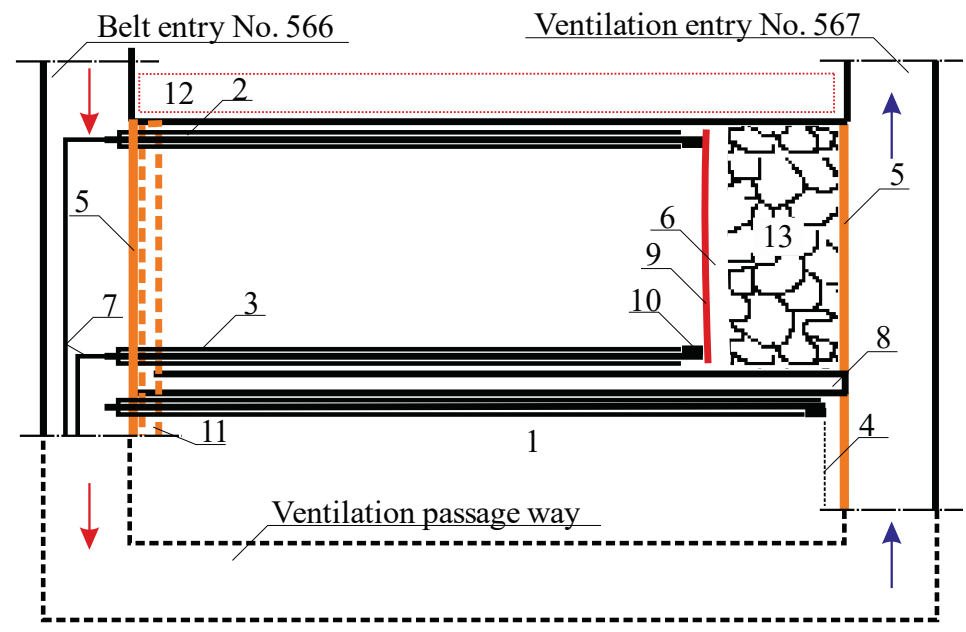

Fig. 1. Extract from the plan of mine workings (a) and $t$ echnological scheme of coal gasification from mine workings (b): 1 - gasification column, 2 - blowing well, 3 - gas-outlet well, 4 - berm, 5 heat-resistant stopping, 6 - reaction channel, 7 - flexible pipeline, 8 - coal pillars, 9 - fire face, $10-$ nose-pieces on a flexible pipeline, 11 - (gas outlet channel) flexible metallic pipeline; 12 - protective pillar of the main southern belt entry; 13 - goaf; 14 - ventilation passage way.

According to the developed design solutions, the technology of coal gasification in the extraction pillar of Stepova mine will be as follows.

Development wells are drilled throughout the whole column length along the length of the extraction pillar of a gas generator (1) on the part of belt entry 566.

A mine gas generator is prepared from belt entry 566 (1) with the help of the blowing (2) and gas-outlet (3) wells along the coal seam. On the part of 566 entry belt, extraction column of a gas generator (1) is contoured with the mounting berm (4) and separated from the entry with the heat-resistant stopping (5); in addition, on the part of 567 entry belt, the 
mounting berm (4) is constructed in which the reaction channel (6) is formed. Elements of the controlled blowing supply are installed in the mounting berm (4). The flexible controlled pipeline (7) is mounted in the blowing (2) and gas-outlet (3) wells. When mounting operations are completed, the berm (4) is separated from 567 ventilation drift by means of the heat-resistant stopping (5). In this context, it should be pointed out that coal pillars of $3-5 \mathrm{~m}$ width (8) are left between the gasification units.

For the ventilation of underground workings at the end of the extraction pillar ventilation passage way is conduct (14). The resulting generator gas is directed to the earth's surface through a gas outlet channel (11). Degassing wells are bored into the crosssection plane from the earth's surface.

A system of the development of mine gas generators means application of the flexible pipelines (7) with the internal diameter of $28 \mathrm{~cm}$ and external diameter of $33.5 \mathrm{~cm}$ in reels. A mixer-regulator of the blowing components is used for stable supply of a blowing mixture to the source of the fire face (9). It provides continuous blowing supply through the main development wells and flexible controlled pipelines along the advancement of the fire face of a gas generator. Use of such a complex system of blowing supply provides the supplying and control of the active blowing reagents $\left(\mathrm{O}_{2}, \mathrm{O}_{2}+\mathrm{CO}\right.$, overheated steam) onto the fire face of the reaction channel of a gas generator.

A coal seam is fired in terms of the combination of the blowing well (2) and the reaction channel of a gas generator (6) with the help of the flexible controlled pipeline (7). Nosepieces on the pipeline end (10) have a lateral opening directed towards the "mirror" of the fire face (9) of a mine gas generator which makes it possible to use them for supplying the blowing mixtures, firing, and reversing. During the gasification, certain temperature range is specified to be controlled during the firing by balancing the pressure and composition of blowing throughout the gasification column length; in our case, for $\mathrm{G} 520$ coal grade, the temperature is $650^{\circ} \mathrm{C}$.

In the process of gasification, the flexible metallic pipeline (7) advances behind the fire face (9) along the blowing well (2). To balance the fire face advance, its active zones are reversed. In terms of reversing, the flexible metallic pipeline (7) advances along the well (3).

During the gasification of a coal seam, blowing mixture is directed onto the "mirror" of the fire face (11) through the perforated nose-pieces (10) mounted on the connections of the blowing (2) and gas-outlet (3) wells with the reaction channel of a gas generator (9).

In this case plasma flow or gas flow can be applied [46-48]. The obtained temperature mode helps provide stable and active kinetics of chemical reactions during the coal gasification. While gasifying the coal of grade $\mathrm{G}$, temperature of the outgoing gas in the gas-outlet well is within the range of $T=820-870^{\circ} \mathrm{C}$, and, during the outgoing from a gas generator, $T=708-756^{\circ} \mathrm{C}$ in terms of pressure $\mathrm{P}=1.9-2.2 \mathrm{~atm}$.

Arrangement of the nose-pieces (10) at the points of the reagents supply to the reaction channel (6) provides an independent source of the high-temperature effect which stipulates the controllability for the coal gasification process in different modes (either autothermal or periodic allothermal ones).

Physicochemical processes connected with the changes in chemical composition and properties of the coal as well as structural features of a mine gas generator are the important and diverse group of the processes of underground coal gasification [49]. Controllability, safety, and technological effectiveness of the syngas production depend on the interaction (balance) of the "underground generator" system, velocities of chemical reactions and physical processes while coal seam degassing. Material balance of the underground coal gasification demonstrates the ratio of debit and credit of the material masses of their volumetric indices in the process $[50,51]$. Qualitative and quantitative parameters of a generator gas are obtained on the basis of the composition of a blowing mixture and qualitative characteristics of the coal (Table 1 and 2). 
Table 1. Indices of the UCG parameters in terms of different types of blowing.

\begin{tabular}{|c|c|c|c|c|c|c|c|c|c|c|c|c|}
\hline \multirow{2}{*}{$\begin{array}{c}\text { Blowing } \\
\text { type }\end{array}$} & \multicolumn{3}{|c|}{$\begin{array}{c}\text { Blowing composition, } \\
\%\end{array}$} & \multicolumn{7}{|c|}{ Composition of the outgoing gases, $\%$} & \multirow{2}{*}{$\underset{\mathrm{mJ} / \mathrm{m}^{3}}{Q,}$} & \multirow{2}{*}{$\begin{array}{c}\mathrm{CE}, \\
\%\end{array}$} \\
\hline & $\mathrm{O}_{2}$ & $\mathrm{CO}_{2}$ & steam & $\mathrm{H}_{2}$ & $\mathrm{CH}_{4}$ & $\mathrm{CO}$ & $\mathrm{N}_{2}$ & $\mathrm{H}_{2} \mathrm{~S}$ & $\mathrm{CO}_{2}$ & $\mathrm{O}_{2}$ & & \\
\hline $\mathrm{O}_{2} \mathrm{~N}_{2}$ & 21 & - & - & 9.1 & 6.0 & 18.4 & 55.8 & 0.35 & 9.3 & 1.2 & 5.3 & 52.0 \\
\hline $\mathrm{O}_{2} \mathrm{~N}_{2}$ & 66 & - & - & 18.7 & 10.2 & 30.7 & 20.4 & 0.8 & 16.0 & 3.2 & 9.5 & 67.5 \\
\hline $\mathrm{O}_{2} \mathrm{~N}_{2}$ & 61 & - & - & 16.5 & 12.4 & 33.8 & 20.0 & 0.7 & 14.1 & 2.5 & 9.6 & 66.4 \\
\hline $\mathrm{H}_{2} \mathrm{O}+\mathrm{O}_{2}$ & 23 & - & 8.0 & 8.1 & 6.1 & 21.4 & 52.5 & 0.5 & 10.0 & 1.4 & 5.8 & 54.6 \\
\hline \multirow{2}{*}{$\mathrm{H}_{2} \mathrm{O}+\mathrm{O}_{2}$} & 56 & - & 195 & 15.3 & 10.6 & 37.4 & 8.2 & 1.3 & 23.2 & 4.0 & 10.2 & 68.3 \\
\hline & 53 & - & 30.6 & 11.6 & 10.4 & 38.6 & 7.3 & 1.0 & 27.2 & 3.9 & 11.2 & 69.0 \\
\hline \multirow{3}{*}{$\mathrm{CO}_{2}+\mathrm{O}_{2}$} & 54 & 42.0 & - & 16.5 & 10.1 & 49.6 & 1.3 & 1.3 & 17.8 & 3.4 & 10.8 & 68.2 \\
\hline & 50 & 30.7 & - & 15.7 & 9.4 & 45.8 & 2.1 & 1.1 & 22.5 & 3.4 & 9.9 & 65.0 \\
\hline & 50 & 38.5 & - & 15.8 & 9.8 & 49.4 & 2.1 & 1.2 & 18.3 & 3.4 & 11.5 & 68.7 \\
\hline \multirow{2}{*}{$\begin{array}{c}\mathrm{CO}_{2}+\mathrm{C}_{2}+ \\
+\mathrm{H}_{2} \mathrm{O}\end{array}$} & 52 & 34.4 & 15.4 & 16.5 & 11.5 & 47.6 & 2.9 & 0.9 & 17.3 & 3.3 & 11.0 & 68.5 \\
\hline & 44 & 36.9 & 11.0 & 16.0 & 9.5 & 50.3 & 2.6 & 0.9 & 17.5 & 3.2 & 10.7 & 67.9 \\
\hline
\end{tabular}

Table 2. Technological parameters of the gasification process for one underground gas generator with the dimensions of $275 \times 30 \times 0.9 \mathrm{~m}$.

\begin{tabular}{|c|c|c|c|c|c|c|}
\hline $\begin{array}{c}\text { Pressure } \\
\text { in a fire } \\
\text { channel, } \\
P, \mathrm{MPa}\end{array}$ & $\begin{array}{c}\text { Temperatu- } \\
\text { re of the } \\
\text { process, } \\
T,{ }^{\circ} \mathrm{C}\end{array}$ & $\begin{array}{c}\text { Temperature } \\
\text { of gases in a } \\
\text { vertical well, } \\
T_{g},{ }^{\circ} \mathrm{C}\end{array}$ & $\begin{array}{c}\text { Advance } \\
\text { rate of a } \\
\text { fire face, } \\
\mathrm{m} / \text { day }\end{array}$ & $\begin{array}{c}\text { Keeping the } \\
\text { parity of an } \\
\text { oxidizing - } \\
\text { reducing } \\
\text { zone }\end{array}$ & $\begin{array}{c}\text { Heat } \\
\text { power of a } \\
\text { gas } \\
\text { generator, } \\
G_{\text {cal }} / \text { hour }\end{array}$ & $\begin{array}{c}\text { Electric } \\
\text { power of a } \\
\text { gas generator, } \\
\mathrm{kW} / \text { hour }\end{array}$ \\
\hline $1.6-3.0$ & $\begin{array}{c}1050- \\
1250\end{array}$ & $350-6000$ & $0.5-2.2$ & $\begin{array}{c}0.3-0.7 \\
0.4-0.6\end{array}$ & $5.0-8.0$ & $5760-9280$ \\
\hline
\end{tabular}

Heat balance indicates the heat exchange in the system of underground gas generator (obtained, used, and lost heat energy) [52-54]. Heat balance is measured in the energy units (Joules, calories) or in per cent of the total amount of heat for a unit of the obtained gas, time unit or unit of the lost substance (coal) (Table 3).

The results represented in Table 3 make it possible to tell about energy potential of the gasification process which will help provide energy needs of a mine gas generator $(8 \%)$ and heat conversions of the industrial gas $(11 \%)$ of the one produced by electric and heat energy in a cogeneration closed technological cycle.

In terms of considerable participation of water steam in the gasification process, there is a significant increase of $\mathrm{H}_{2}$ concentration and decrease of $\mathrm{CH}_{4}$ and $\mathrm{CO}$ that is connected with the low-temperature conditions of the gasification process [55-57]. Reducing calorific property of the gas under those conditions can be explained by the reaction of conversion:

$$
\mathrm{CO}+\mathrm{H}_{2} \mathrm{O}+\mathrm{CO}_{2}=\mathrm{CO}_{2}+\mathrm{H}_{2}+41.8 \mathrm{~kJ} / \text { mole, }
$$

That reaction favours the increase in the amount of steam within the gasification zone. The proposed combined method of the blowing mixture supply and outlet of the underground gasification products for the conditions of Stepova mine facilitates the formation of the discharge zone in the gasification area. That provides additional hydroinsulation of the reaction channel of a gas generator owing to the redistribution of the flows of static ground waters of the coal-overlaying rock strata. The represented model to control water inflow within the gasification zone takes into consideration mining and geological, hydrogeological, and geomechanical parameters of the rock mass (changes in lithological and filtration properties of the coal-overlaying strata) as well as technological indices of the process (combined system of the blowing supply and removal of the 
generator gas which provides water removal from the reaction channel and water distribution throughout the gas-outlet well). The proposed model was approbated during the laboratory and stand studies which took into account nonstationary geofiltration state of the underground gas generator under conditions of changes of high temperatures of the process and continuity of the coal-overlaying strata during the coal seam gasification $[58,59]$.

Table 3. Heat balance of the underground gasification of a coal seam of a mine well-gas generator.

\begin{tabular}{|c|c|c|c|c|c|c|}
\hline \multirow{3}{*}{ Parameters } & \multicolumn{6}{|c|}{ Blowing composition } \\
\hline & \multicolumn{2}{|c|}{ Air } & \multicolumn{2}{|c|}{ Oxygen } & \multicolumn{2}{|c|}{$\begin{array}{l}\mathrm{O}_{2}+\mathrm{CO}_{2}+ \\
\text { steam }\end{array}$} \\
\hline & $\mathrm{mJ} / \mathrm{kg}$ & $\%$ & $\mathrm{~mJ} / \mathrm{kg}$ & $\%$ & $\mathrm{~mJ} / \mathrm{kg}$ & $\%$ \\
\hline \multicolumn{7}{|c|}{ Heat emission } \\
\hline Calorific value per as-fired fuel & 31.993 & 97.43 & 31.993 & 90.57 & 31.993 & 90.57 \\
\hline $\begin{array}{l}\text { Heat capacity of the mass within the oxidizing } \\
\text { zone }\end{array}$ & 0.636 & 1.93 & 1.272 & 3.60 & 1.272 & 3.60 \\
\hline Heat capacity of the blowing & 0.208 & 0.64 & 2.087 & 5.83 & 2.087 & 5.83 \\
\hline Total: & 32.837 & 100.00 & 35.352 & 100 & 35.352 & 100 \\
\hline Calorific value of the WUCG gas & 11.920 & 36.33 & 15.640 & 44.45 & 14.596 & 42.43 \\
\hline \multicolumn{7}{|c|}{ Heat losses } \\
\hline Heating of ash and slag & 0.095 & 0.30 & 0.095 & 0.26 & 0.095 & 0.27 \\
\hline Heating and use of moisture & 0.375 & 1.14 & 0.375 & 1.10 & 0.375 & 1.09 \\
\hline Heating of the enclosing rocks & 6.805 & 20.80 & 5.858 & 16.70 & 6.211 & 18.04 \\
\hline Heat capacity of the dry generator gas & 13.593 & 41.43 & 13.196 & 37.50 & 13.32 & 38.70 \\
\hline Total: & 32.788 & 100.00 & 35.164 & 100 & 34.397 & 100 \\
\hline $\begin{array}{l}\text { Temperature at the outlet from a reaction } \\
\text { channel, }{ }^{\circ} \mathrm{C}\end{array}$ & \multicolumn{2}{|c|}{427} & \multicolumn{2}{|c|}{697} & \multicolumn{2}{|c|}{648} \\
\hline $\begin{array}{l}\text { Temperature of the UCG gases at their outlet } \\
\text { from a gas-outlet well, }{ }^{\circ} \mathrm{C}\end{array}$ & \multicolumn{2}{|c|}{234} & \multicolumn{2}{|c|}{383} & \multicolumn{2}{|c|}{356} \\
\hline
\end{tabular}

Parameters and indices of coal gasification in the extraction column of a mine gas generator are connected immediately with the extraction pillar reserves. The practice of Stepova mine shows the expedience of leaving the protective pillars near the main drifts $(50-85 \mathrm{~m})$. Thus, the coal reserves to be involved for gasification are determined as follows (Fig. 1):

- specify the "effective" length of the gasification column:

$$
L_{\text {l.g.c }}=L_{g . c}-b-l \cdot n, \mathrm{~m}
$$

where $L_{g . c}$ is length of the gasification column, $\mathrm{m} ; b$ is width of a protective pillar, $\mathrm{m} ; l$ is width of a preventive pillar, $\mathrm{m} ; n$ is number of the preventive pillars along the gasification column.

- determine the coal reserves to be gasified:

$$
Z=L_{\text {l.g.c }} \cdot l_{f . f} \cdot m \cdot \gamma, \mathrm{m}
$$

where $l_{f f f}$ is length of a fire face, $\mathrm{m} ; m$ is thickness of a coal seam, $\mathrm{m} ; \gamma$ is volumetric weight of the coal, $\mathrm{t} / \mathrm{m}^{3}$.

Coal gasification within the column boundaries (Fig. 1) makes it possible to get $1.73-$ $2.30 \mathrm{mln} \mathrm{m}^{3}$ of gas in terms of average generator gas output of $1800-2400 \mathrm{~m}^{3} / \mathrm{t}$ of coal. According to Table 1, a share of combustion gases, e.g. in terms of air blowing $\left(\mathrm{O}_{2}=21 \%\right)$, will be $0.5-0.77 \mathrm{mln} \mathrm{m}^{3}$ of gas. 


\section{Conclusions}

The technology of underground coal gasification in terms of Lvivvuhillia SE is efficient while developing on- and off-balance overworked and underworked reserves of coal mines of the region. It does not require considerable costs for opening and preparation of the underlying levels; it also solves important social problems concerning the miners' employment.

Mining and geological conditions of the coal seam occurrence as well as mining and technical situation during the implementation of the underground coal gasification technology play an important part having both positive and negative effect on the gasification process.

The process of design and operation of the underground gas generators should involve a set of following factors: water content of the seam and the enclosing rocks, tectonic disturbance of the rock mass, chemical and technical composition of the coal and the enclosing rocks, mechanical and thermal properties of the coal seam and the enclosing rock, geochemical parameters of the rock and their changes during degassing (caving step, zones of technological fissility, parameters of bearing pressure), thickness of the coal seam as well as roof and floor rocks, rock mass structure, dip angle of the seam. Length of the extraction pillar, parameters of the fire face, and technology of the blowing mixture supply into the fire face are the basic technological factors influencing the gasification process.

The technological scheme of the gasification process for mining and geological conditions of Lvivvuhillia SE, i.e. Stepova mine, has been proposed on the basis of the analytical, laboratory, and industrial studies. Material and heat indices of the gasification process have been analyzed.

This work was supported by the Ministry of Education and Science of Ukraine, grants entitled: "Synthesiss, optimization and parameterization of innovative technologies for development of gas-coal resources" and "Geotechnological bases of power and chemical complexes formation in the coal mining region".

\section{References}

1. Piwniak, G.G., Bondarenko, V.I., Salli, V.I., Pavlenko, I.I., Dychkovskiy, R.O. (2007). Limits to economic viability of extraction of thin coal seams in Ukraine. Technical, Technological and Economic Aspects of Thin-Seams Coal Mining, 129-132

2. Bulat, A., Lukinov, V., Perepelitsa, V. (2011). Results of realized new concept of complex coal-gas deposit development. Technical and Geoinformational Systems in Mining: School of Underground Mining, 13-18

3. Churin, V., Vysotskaya, N., Sizova, Yu., Danilina, E., Gorelov, D. (2019). Distribution of mineral extraction revenue: overview of international practice. Mining of Mineral Deposits, 13(2), 66-74

4. Medunić, G., Mondol, D., Rađenović, A., Nazir, S. (2018). Review of the latest research on coal, environment, and clean technologies. Rudarsko Geolosko Naftni Zbornik, 33(3), 13-21

5. Falshtynskyi, V., Saik, P., Lozynskyi, V., Dychkovskyi, R., Petlovanyi, M. (2018). Innovative aspects of underground coal gasification technology in mine conditions. Mining of Mineral Deposits, 12(2), 68-75

6. Falshtynskyi, V.S., Dychkovskyi, R.O., Saik, P.B., Lozynskyi, V.H., Cabana, E.C. (2017). Formation of thermal fields by the energy-chemical complex of coal gasification. Naukovyi Visnyk Natsionalnoho Hirnychoho Universytetu, (5), 36-42 
7. Bondarenko, V., Tabachenko, M., Wachowicz, J. (2010). Possibility of production complex of sufficient gasses in Ukraine. New Techniques and Technologies in Mining, 113-119

8. Burchart-Korol, D., Krawczyk, P., Czaplicka-Kolarz, K., Smoliński, A. (2016). Ecoefficiency of underground coal gasification (UCG) for electricity production. Fuel, (173), 239-246

9. Śliwińska, A., Burchart-Korol, D., Smoliński, A. (2017). Environmental life cycle assessment of methanol and electricity co-production system based on coal gasification technology. Science of the Total Environment, (574), 1571-1579

10. Kalybekov, T., Rysbekov, K.B., Toktarov, A.A., Otarbaev, O.M. (2019). Underground mine planning with regard to preparedness of mineral reserves. Mining Informational and Analytical Bulletin, (5), 34-43

11. Demydov, M. (2020). Solutions multivariance about designing new levels of coal mines. Rudarsko Geolosko Naftni Zbornik, 35(2). Accepted paper

12. Ilyashov, M. Diedich, I., \& Nazimko, V. (2019). Prospective tendencies of coal mining risk management. Mining of Mineral Deposits, 13(1), 111-117

13. Dychkovskyi, R.O. (2015). Forming the bilayer artificially created shell of georeactor in underground coal well gasification. Naukovyi Visnyk Natsionalnoho Hirnychoho Universytetu, (5), 37-42

14. Tabachenko, M. (2016). Substantiating parameters of stratification cavities formation in the roof rocks during underground coal gasification. Rozrobka rodovyshch, 10(1), 16-24

15. Saik, P., Petlevanyi, M., Lozynskyi, V., Sai, K., Merzlikin, A. (2018). Innovative approach to the integrated use of energy resources of underground coal gasification. Solid State Phenomena, (277), 221-231

16. Pivniak, H.H., Pilov, P.I., Pashkevych, M.S., Shashenko, D.O. (2012). Synchro-mining: Civilized solution of problems of mining regions' sustainable operation. Naukovyi Visnyk Natsionalnoho Hirnychoho Universytetu, (3), 131-138

17. Pivnyak, G.G., Shashenko, O.M. (2015). Innovations and safety for coal mines in Ukraine. Naukovyi Visnyk Natsionalnoho Hirnychoho Universytetu, (6), 118-121.

18. Malanchuk, Z., Moshynskyi, V., Malanchuk, V., Korniienko, Y., Koziar, M. (2020). Results of Research into the Content of Rare Earth Materials in Man-Made Phosphogypsum Deposits. Key Engineering Materials, (844), 77-87

19. Vladyko, O., Kononenko, M., Khomenko, O. (2012). Imitating modeling stability of mine workings. Geomechanical Processes During Underground Mining, 147-150

20. Yun, Z., Jianfang, S., Zhongchun, L. (2019). Study of numerical simulation method modelling gas injection into fractured reservoirs. Mining of Mineral Deposits, 13(2), 4145

21. Pivnyak, G., Dychkovskyi, R., Bobyliov, O., Cabana, E.C., Smoliński, A. (2018). Mathematical and Geomechanical Model in Physical and Chemical Processes of Underground Coal Gasification. Solid State Phenomena, (277), 1-16

22. Krasnyk, V. (2017). Modeling the process of mineral rocks cutting with a tool made of polycrystalline superhard materials. Mining of Mineral Deposits, 11(3), 84-92

23. Pivnyak, G., Dychkovskyi, R., Smirnov, A., Cherednichenko, Y. (2013). Some aspects on the software simulation implementation in thin coal seams mining. Energy Efficiency Improvement of Geotechnical Systems, 1-10

24. Ali, M.A.M. (2018). Software application in mining engineering. Mining of Mineral Deposits, 12(1), 48-53

25. Sarycheva, L. (2003). Using GMDH in ecological and socio-economical monitoring problems. Systems Analysis Modelling Simulation, 43(10), 1409-1414

26. Popovych, V., Voloshchyshyn, A. (2019). Features of temperature and humidity conditions of extinguishing waste heaps of coal mines in spring. News of the National 
Academy of Sciences of the Republic of Kazakhstan, Series of Geology and Technical Sciences, 4(436). 230-237

27. Ramayah, M., Rasiah, R., Somasundram, S., Turner, J.J. (2019). Determinants of environmental degradation: reflections on the impact of identified economic variables on the environment. Mining of Mineral Deposits, 13(4), 42-52

28. Son, N.L.H., Anh, N.H., Dong, H.N. (2016). Review of Underground Coal Gasification Technologies. Proceedings $-3^{\text {rd }}$ International Conference on Green Technology and Sustainable Development, 7796621, 69-73

29. Shafirovich, E., Varma, A. (2009). Underground coal gasification: A brief review of current status. Industrial and Engineering Chemistry Research, 48(17), 7865-7875.

30. Basu, R. (2017). Evaluation of some renewable energy technologies. Mining of Mineral Deposits, 11(4), 29-37

31. Xin, L., Wang, Z., Huang, W., Kang, G., Lu, X., Zhang, P., Wang, J. (2014). Temperature field distribution of burnt surrounding rock in UCG stope. International Journal of Mining Science and Technology, 24(4), 573-580

32. Falshtynskyi, V., Dychkovskyi, R., Lozynskyi, V., Saik, P. (2015). Analytical, laboratory and bench test researches of underground coal gasification technology in National Mining University. New Developments in Mining Engineering, 97-106

33. Xin, L., Cheng, W., Xie, J., Liu, W., Xu, M. (2019). Theoretical research on heat transfer law during underground coal gasification channel extension process. International Journal of Heat and Mass Transfer, (142),118409

34. Su, F., Itakura, K., Deguchi, G., Ohga, K., Goto, T. (2012). Laboratory studies on evaluation of gasification effect for conversion of coal resources in underground coal gasification (UCG) reactors. Advanced Materials Research, (600), 111-115

35. Dychkovskyi, R.O. (2015). Determination of the rock subsidence spacing in the well underground coal gasification. Naukovyi Visnyk Natsionalnoho Hirnychoho Universytetu, (6), 30-36

36. Kostúr, K., Kačúr, J. (2008). The monitoring and control of underground coal gasification in laboratory conditions. Acta Montanistica Slovaca, 13(1), 111-117

37. Lozynskyi, V.G., Dychkovskyi, R.O., Falshtynskyi, V.S., Saik, P.B., Malanchuk, Ye.Z. (2016). Experimental study of the influence of crossing the disjunctive geological faults on thermal regime of underground gasifier. Naukovyi Visnyk Natsionalnoho Hirnychoho Universytetu, (5). 21-29

38. Kapusta, K., Stańczyk, K., Wiatowski, M., Chećko, J. (2013). Environmental aspects of a field-scale underground coal gasification trial in a shallow coal seam at the Experimental Mine Barbara in Poland Fuel, (113), 196-208

39. Sarhosis, V., Kapusta, K., Lavis, S. (2018). Underground coal gasification (UCG) in Europe: Field trials, laboratory experiments, and EU-funded projects. Underground Coal Gasification and Combustion, 129-171

40. Perkins, G. (2018). Underground coal gasification - Part I: Field demonstrations and process performance. Progress in Energy and Combustion Science, (67), 158-187.

41. Pivnyak, G., Bondarenko, V., Kovalevs'ka, I., Illiashov, M. (2012). Geomechanical Processes During Underground Mining, 238 p. Book

42. Khomenko, O.Ye. (2012). Implementation of energy method in study of zonal disintegration of rocks. Naukovyi Visnyk Natsionalnoho Hirnychoho Universytetu, (4), 44-54

43. Malanchuk, Z.R., Moshynskyi, V.S., Korniienko, V.Y., Malanchuk, Y.Z., Lozynskyi, V.H. (2019). Substantiating parameters of zeolite-smectite puff-stone washout and migration within an extraction chamber. Naukovyi Visnyk Natsionalnoho Hirnychoho Universytetu, (6), 11-18 
44. Wiatowski, M., Stańczyk, K., Świadrowski, J., (2012). Semi-technical underground coal gasification (UCG) using the shaft method in Experimental Mine "Barbara". Fuel, (99), 170-179

45. Falshtyns'kyy, V., Dychkovs'kyy, R., Stanczyk, K., Swiadrowski, J. (2010). Analytical determination of parameters of material and thermal balance and physical parameters of a coal seam work-out on mine "Barbara", Poland. New Techniques and Technologies in Mining, 161-165

46. Voloshyn, O., Potapchuk, I., Zhevzhyk, O., Yemelianenko, V., Horiachkin, V., Zhovtonoha, M., Semenenko, Ye., Tatarko, L. (2018). Study of the plasma flow interaction with the borehole surface in the process of its thermal reaming. Mining of Mineral Deposits, 12(3), 28-35.

47. Bulat, A., Voloshyn, O., Zhevzhik, O. (2013). Plasma reactor for thermochemical preparation of coal-air mixture before its burning in the furnaces. Annual ScientificTechnical Colletion - Mining of Mineral Deposits, 39-44

48. Golovchenko, A. (2020). Some aspects of the control for the radial distribution of burden material and gas flow in the blast furnace. Energies, 13(4), 923-926

49. Falshtyns'kyy, V., Dychkovs'kyy, R., Lozyns'kyy, V., Saik, P. (2013). Justification of the gasification channel length in underground gas generator. Annual ScientificTechnical Colletion - Mining of Mineral Deposits, 125-132

50. Lozynskyi, V., Saik, P., Petlovanyi, M., Sai, K., Malanchuk, Z., Malanchuk, Y. (2018). Substantiation into mass and heat balance for underground coal gasification in faulting zones. Inzynieria Mineralna, 19(2), 289-300

51. Laciak, M., Kačur, J., Durdán, M. (2011). Material and energy balance of the UCG process in the laboratory conditions. Modern Management of Mine Producing, Geology and Environmental Protection, (3), 69-76

52. Fischer, D D., Boysen, J.E., Gunn, R.D. (1977). Energy balance for the second underground coal gasification experiment, Hanna, Wyoming. Trans Soc Min Eng AIME, 262(4), 341-347

53. Sawyer, W.K., Shuck, L.Z. (1976). Numerical simulation of mass and energy transfer in the longwall process of underground gasification of coal. Symposium on Numerical Simulation of Reservoir Performance, 355-365

54. Lozynskyi, V., Dychkovskyi, R., Saik, P., Falshtynskyi, V. (2018). Coal Seam Gasification in Faulting Zones (Heat and Mass Balance Study). Solid State Phenomena, (277), 66-79

55. Gür, M., Canbaz, E.D. (2020). Analysis of syngas production and reaction zones in hydrogen oriented underground coal gasification. Fuel, (269), 117331

56. Yang, L.H., Zhang, X., Zhu, K. (2016). Hydrogen production in underground coal gasification (UCG). Energy Sources, Part A: Recovery, Utilization and Environmental Effects, 38(3), c. 376-383

57. Liu, S.Q., Wang, Y.Y., Zhao, K., Yang, N. (2009). Enhanced-hydrogen gas production through underground gasification of lignite. Mining Science and Technology, 19(3), 389-394

58. Falshtynskyi, V., Dychkovskyi, R., Saik, P., Lozynskyi, V. (2014). Some aspects of technological processes control of an in-situ gasifier during coal seam gasification. Progressive Technologies of Coal, Coalbed Methane, and Ores Mining, 109-112.

59. Saik, P.B., Dychkovskyi, R.O., Lozynskyi, V.H., Malanchuk, Z.R., Malanchuk, Ye.Z. (2016). Revisiting the underground gasification of coal reserves from contiguous seams. Naukovyi Visnyk Natsionalnoho Hirnychoho Universytetu, (6), 60-66 